\title{
ЛІТЕРАТУРОЗНАВСТВО
}

\section{PERCEPCJA KIJOWA \\ W TWÓRCZOŚCI ALEKSANDRA KUPRINA}

\author{
ANTONI BORTNOWSKI \\ Uniwersytet imienia Adama Mickiewicza, Poznań — Polska \\ a.bortnowski@amu.edu.pl \\ СПРИЙНЯТТЯ КИЄВА У ТВОРЧОСТІ ОЛЕКСАНДРА КУПРІНА \\ АНТОН БОРТНОВСЬКИЙ \\ Університет імені Адама Міцкевича, Познань - Польща
}

\begin{abstract}
АНОТАЦІЯ. Олександр Купрін був російським письменником, який на ранньому етапі свого життя потрапив до Києва. Сім років (1892-1899), які він провів у цьому місті, мали потужний вплив на всю його творчість. Образи Києва з'являються не тільки у збірці Київські типи (1896), але також у пізніших творах письменника, зокрема еміграційних. Олександр Купрін був справжнім реалістом, який з великою точністю намагався відобразити специфіку довкілля, завдяки чому на сторінках його творів репрезентована вся різноманітність київського життя к. XIX - поч. XX століття.
\end{abstract}

\section{PERCEPTION OF KIEV IN ALEKSANDR KUPRIN'S OUTPUT}

\author{
ANTONI BORTNOWSKI \\ Adam Mickiewicz University, Poznan — Poland
}

\begin{abstract}
ABSRACT. Alexander Kuprin was a Russian writer who came to Kiev early in his life. Those seven years (1892-1899) that he spent in the city had a huge impact on all his work. The images of Kiev appeared not only in his collection of sketches The Kiev Types (1896), but also in the later works of the writer, including the emigration period. Alexander Kuprin was a true realist, who, with great precision, tried to recapture the specifics of the reality around him. As a result, the pages of his writings reflect all the diversity of the Kiev life of the late nineteenth and early twentieth century.
\end{abstract}

$\mathrm{R}$ olę miast w procesie kształtowania tożsamości narodowej, rozwoju kultury i cywilizacji ciężko jest przecenić. Ośrodki miejskie zawsze były centrami wymiany myśli, w nich formowały się i ścierały idee mające wpływ na rozwój całych narodów. Wiele $\mathrm{z}$ metropolii $\mathrm{w}$ toku procesu historycznego uzyskało rangę symboli kulturotwórczych, nieodłącznych elementów tradycji narodowej. W przypadku Rosji taką rolę bez wątpienia odgrywały (i nadal odgrywają) "dwie stolice" Moskwa i Sankt-Petersburg. W wypadku Ukrainy sytuacja jest natomiast znacznie bardziej złożona, gdyż w wyniku wielowiekowego braku własnej państwowości kultura ukraińska dopiero w XX wieku otrzymała możliwość nieskrępowanego rozwoju w warunkach przestrzeni miejskiej, tradycyjnie w większym stopniu niż prowincja ulegającej wpływom metropolii. W rezultacie mamy do czynienia z sytuacją, gdy nawet stolica współczesnej Ukrainy — Kijów — wciąż znajduje się w procesie "porządkowania" swojej wielokulturowej przeszłości, nie ograniczającej się wyłącznie 
do spuścizny narodu ukraińskiego. Należy pamiętać, że miasto swego czasu było ośrodkiem rozwoju nie tylko kultury ukraińskiej czy rosyjskiej, ale także żydowskiej oraz polskiej.

Sytuację komplikuje dodatkowo fakt, że zarówno na Ukrainie jak i w Rosji Kijów postrzega się jako kolebkę swojej państwowości. Potwierdzają to nie tylko aktualne wydarzenia, jak na przykład uroczyste otwarcie w listopadzie 2016 roku moskiewskiego pomnika księcia kijowskiego Włodzimierza, ale także obrazy Kijowa jako "matki miast ruskich" ("мать городов русских"), trwale zakorzenione w kulturze rosyjskiej. Literatura piękna w tym wypadku najlepiej obrazuje wspomniany stan rzeczy. Już Aleksander Puszkin pisał:,наш Киев дряхлый, златоглавый, сей пращур русских городов" ${ }^{\prime 2}$, ale najpowszechniej znany obraz Kijowa w literaturze rosyjskiej pojawił się niemal sto lat później w Białej gwardii (1925) Michaiła Bułhakowa. Autor Mistrza i Małgorzaty w odróżnieniu od Puszkina był dodatkowo osobiście związany z miastem nad Dnieprem, w którym się urodził i wychował. Należy pamiętać jednak, że z Kijowa pochodzą także inni pisarze rosyjscy, którzy uwiecznili w swojej twórczości obraz miasta rodzinnego. Do tej grupy można zaliczyć niewątpliwie Ilję Erenburga, Konstantina Paustowskiego czy Wiktora Niekrasowa. Jednym z twórców, który znaczącą część swojego życia spędził w Kijowie, chociaż pochodził z innego regionu ówczesnego Imperium Rosyjskiego, był z kolei Aleksander Kuprin (1870-1938).

Autor Pojedynku trafił do miasta nad Dnieprem tuż po służbie wojskowej i to właśnie w ciągu siedmiu kijowskich lat (1892-1899) ukształtował się jako pisarz, wyraźnie określając wątki, które później zdominowały jego twórczość 3 . W tym okresie ukazał się nie tylko pierwszy zbiór szkiców i opowiadań Kuprina Miniatury $(\mathrm{Mu}$ ниатюры, 1897), ale także utwory, z którymi do dzisiaj kojarzone jest nazwisko pisarza — opowieści Moloch (Молох, 1896) і Olesia (Олеся, 1898). Obecność Kijowa w utworach Kuprina i wpływ miasta na jego twórczość nie ogranicza się jednak wyłącznie do lat 90 XIX wieku. Miron Piotrowski nazywa wręcz autora Pojedyn$k u$ "kijowskim pisarzem", który w pewnym sensie musiał natchnać samego Michaiła Bułhakowa4 . Aleksander Kuprin utrwalił w swojej twórczości obraz Kijowa przełomu XIX i XX wieku, a fakt, że dla pisarza uczciwe i rzetelne odzwierciedlenie zjawisk otaczającego go świata było kwestią priorytetową, dodaje w tym zakresie jakże cennego autentyzmu. W wielu pracach poświęconych klasykowi literatury rosyjskiej wspomina się o sformułowanych przez niego "dziesięciu przykazaniach" pisarza-realisty, jedno z których brzmi: ,[...] работай, живя. Ты - репортер жизни. Иди в похоронное бюро, поступи факельщиком, переживи с рыбаками шторм на оторвавшейся льдине, суйся решительно всюду, броди, побывай рыбой, женщиной, роди, если можешь, влезь в самую гущу жизни" ". Kijowska rzeczywistość stała się więc źródłem materiału, który posłużył następnie do stworzenia literackiego obrazu miasta, wyłaniającego się z wielu utworów Kuprina.

Kijowskie realia pojawiają się $\mathrm{w}$ twórczości pisarza wiele lat po opuszczeniu przez niego miasta nad Dnieprem, w tym także w okresie emigracyjnym, gdy Kijów

\footnotetext{
${ }^{1}$ Повесть временных лет, перев. Д. Ли хач ев а, [в:] Электронный ресурс: http://old-russian. chat.ru/01 povest.htm (02.02.2017).

${ }^{2}$ А. Пушки н, Бородинская годовщина, [в:] Полн. собр. соч., в 3-х томах, том I. Стихотворения 1814-1836 годов. Сказки, Москва 1978, с. 305.

${ }^{3}$ А. Афанасье в, А. И. Куприн. Критико-биографический очерк, Москва 1960, с. 26-30.

${ }^{4}$ М. Пе тро в ский, Мастер и Город: Киевские контексты Михаила Булгакова, СПб. 2008, c. 196.

${ }_{5}^{5}$ А. Афанасьев, указ. источ., с. 158.
} 
mógł się wydawać tak samo daleki, jak Moskwa czy Petersburg. Przykładami w tym wypadku mogą być opowiadania Inna (Инна, 1928), Ferdynand (Фердинанд, 1930) czy Udod (Удод, 1932).

Autor Pojedynku, opierając się na obserwacji otaczającej rzeczywistości dążył do ukazania uniwersalnych problemów, swego rodzaju typizacji otoczenia. Dlatego też w wielu pracach miasto, ewidentnie wzorowane na kijowskiej przestrzeni, nie jest wprost nazywane. Fakt ten dotyczy m.in. miejsca akcji Jamy (Яма, 1909, 1915), najobszerniejszego utworu Aleksandra Kuprina, w którym pojawia się bezimienne “wielkie południowe miasto" (“большой южный город”) ${ }^{6}$. W rezultacie w wielu tekstach Kuprina kijowskie konteksty można z łatwością przeoczyć — jeśli nazwa miasta nie zostaje podana, na jego archetyp wskazują często jedynie drobne, aczkolwiek istotne szczegóły świata przedstawionego. $Z$ tego typu sytuacją mamy do czynienia na przykład we wspomnianym opowiadaniu Udod, rozpoczynającym się poetyckim opisem wiosennego miasta: „Червонное зарево заката сквозь гущу ветвей бросало на свежие газоны пурпурные, фиолетовые и лимонные пятна, которые двигались, качались и трепетали. Цветущие паникадила розовых каштанов разливали свой прекрасный, почти человеческий, но греховный запах, от которого у женщин раздуваются и вздрагивают ноздри"”. Oczywiście, kasztany, będące jednym z symboli miasta nad Dnieprem, mogły kwitnąć w wielu miejscach ówczesnej Rosji, ale wspomniane tylko raz miejsce pracy głównego bohatera - siedziba Kolei Południowo-Zachodniej - odsyła czytelnika wprost do Kijowa. Faktu tego oczywiście nie należy przeceniać w kontekście interpretacji tego konkretnego opowiadania, ale uzmysławia on, na ile głęboko w świadomości Kuprina utkwiły obrazy Kijowa, wciąż odradzające się w jego utworach. Miasto nad Dnieprem staje się u pisarza miejscem kojarzącym się z utraconą ojczyzną, minioną młodością i towarzyszącą jej głęboką wiarą w ideały. W tym sensie należy zgodzić się z Mironem Piotrowskim, który zauważa wspólny dla Kuprina i Bułhakowa nostalgiczny stosunek do przedrewolucyjnego Kijowa ${ }^{8}$. Swego rodzaju reminiscencją dawno utraconej rzeczywistości staje się jedno z emigracyjnych opowiadań Kuprina - Inna. Wspomnienie uczucia czystej młodzieńczej miłości zlewa się organicznie z obrazem wiosennego Kijowa. „Ах, этот Киев! Чудесный город, весь похожий на сдобную, славную попадью с масляными глазами и красным ртом. Как мне забыть эти часы, когда, возбужденный теплым тополевым запахом весенней ночи, я ходил из церкви в церковь, не минуя единоверцев, греков и старообрядцев" ". Ten otwierający opowiadanie fragment następuje zaraz po podtytule utworu: Opowieść człowieka bezdomnego (Рассказ бездомного человека), podkreślając kontrast pomiędzy "bezdomnością" narratora i wspomnieniem bliskiej sercu, wręcz swojskiej atmosfery Kijowa. Miasto zdaje się zlewać ze stanami emocjonalnymi bohatera, odzwierciedlając jego szczery i wzniosły zachwyt nad ukochaną, któremu towarzyszą złe przeczuсіа („Сияющие колокольни церквей казались необыкновенно легкими и точно воздушными. В самом низу, прямо подо мною, сине белела еще не тронувшаяся река, с черневшимися на ней зловещими проталинами" $\left.{ }^{10}\right)$. W opowiadaniu Inna Kijów, pojawiając się na początku i końcu utworu, stanowi klamrę kompozycyjną, podkreślając rolę miasta jako nieodłącznego elementu wspomnienia o młodzień-

${ }^{6}$ А. Куп п и , Яма, [в:] Электронный ресурс: http://lib.ru/LITRA/KUPRIN/yama.txt (02.02.2017).

${ }^{7}$ А. Куп п и н, Удод, [в:] Электронный ресурс: http://liv.piramidin.com/belas/Kuprin/udod.htm (02.02.2017).

${ }^{8}$ М. Петровский, указ. источ., с. 196.

${ }^{9}$ А. Купр ин, Инна, [в:] Его же, Собр. соч., в 9-ти томах, Москва 1973, т. 7, с. 415.

${ }^{10}$ Там же, с. 417. 
czym smutku. „Она ушла. Я долго еще сидел на Владимирской горке. Душа моя была ясна и спокойна. Всемогущая судьба прошла надо мною"”. cych opowiadanie słowach Kijów jawi się nie tylko jako sceneria dla miłosnego zawodu młodego bohatera, ale także miejsce, w którym odbywa się duchowe dojrzewanie młodzieńca, połączone $\mathrm{z}$ uświadomieniem sobie istnienia wiecznych i wszechmocnych sił rządzących ludzkim życiem. Po raz kolejny można w tym przypadku zauważyć paralele z twórczością Bułhakowa, a konkretnie z postacią Nikołki z Białej gwardii, który również przechodzi w będącym alter ego Kijowa Mieście proces duchowego dorastania.

Ponad 30 lat przed powstaniem emigracyjnych opowiadań, w których Kuprin wskrzeszał barwne obrazy przedrewolucyjnego Kijowa, miasto na trwałe wpisało się w biografię twórczą autora Jamy za sprawą Kijowskich typów (Киевские mипbl, 1895) - pierwszej książki młodego pisarza. Ten cykl szkiców, przedstawiający barwne sylwetki typowych kijowian końca XIX wieku jest interesujący z kilku powodów. Pierwszym z nich jest fakt, na który zwrócił uwagę A. Afanasjew. Chodzi tutaj o wpływ cyklu na całą dalszą twórczość Kuprina - pisarz w pewnym sensie tworzy szkice postaci, zarysy problemów, które znajdą pełne rozwinięcie w późniejszych utworach ${ }^{12}$. Potwierdza to wcześniejsze słowa o roli kijowskiej przestrzeni jako źródła obserwacji i wątków dla całej dalszej, "postkijowskiej” drogi twórczej Kuprina. Kolejnym powodem, dla którego warto zwrócić się do Kijowskich typów, jest wartość poznawcza cyklu. Ukazuje on bowiem, na ile dokładnym i rzetelnym obserwatorem rzeczywistości był Kuprin, utrwalając obraz kijowskich realiów końca XIX wieku. Jak zauważył inny kijowianin, Konstantin Paustowski, trzeba było posiadać niezwykłą przenikliwość, aby na tyle bezbłędnie przeniknąć wewnętrzną istotę najbardziej różnorodnych ludzi ${ }^{13}$.

Kijów na przełomie XIX i XX wieku stał się jedną z głównych metropolii Imperium Rosyjskiego, co wyraziło się także w przeobrażeniach wizualnej strony miasta. Kuprin zwraca uwagę na ten fakt, odnotowując jednak (często z ironią), że w wielu kwestiach miasto nad Dnieprem wciąż ma wiele do nadrobienia w stosunku do innych ośrodków. „Насколько мне известно, в Киеве нет ни одного специально игорного дома. В этом отношении, несмотря на свою американскую внешность, праматерь русских городов далеко отстала от Петербурга, Москвы и даже Одессы" 14 . Widzimy zatem, że w świadomości Kuprina i jemu współczesnych Kijów znajdował się w "pierwszej lidze" ówczesnych miast rosyjskich, co stoi w sprzeczności z często powtarzanym obecnie obrazem prowincjonalnego gubernialnego miasteczka na peryferiach Imperium ${ }^{15}$. Z Kijowskich typów wyłania się dość spójny wizerunek miasta, w którym powtarzają się charakterystyczne zjawiska.

Pierwszym z nich jest "ogólnorosyjskość", a wręcz "światowość", która dotyczy nie tylko strony wizualnej, ale też, a może nawet przede wszystkim, kijowskich wyższych warstw społecznych. Przejawia się to głównie w zakresie mody i pewnych schematów zachowań. W szkicu Student-dragon (Студент-драгун) pojawia się ob-

11 Там же, с. 419.

12 А. Афанасьев, указ. источ., с. 19.

13 К. Пау с то в с и й, Поток жизни (заметки о прозе Куприна), [в:] А. Куприн, Собр. соч., в 6-ти томах, Москва 1957, том 1, с. 11.

${ }^{14}$ А. Купр и н, Киевские типь: Бенефициант, [в:] Его же, Собр. соч., в 9-ти томах, Москва 1970 , том 1, c. 425.

15 Taki obraz miasta jest przedstawiony, m. in. w powieści współczesnego pisarza ukraińskiego Andrija Kokotiuchy Kijowskie bomby (Київські бомби, 2014): „Київ — місто маленьке насправді” (с. 199), “губернська столиця” (с. 21), wktórej mieszkają “сонні міщани” (с. 220). 
raz młodzieńca, który nie chciałby odstawać w pozerstwie od petersburskich studentów-gwardzistów ${ }^{16}$. Będąc całkowitym ignorantem, umie się on jednak doskonale odnaleźć dzięki znajomości sztampowych haseł: „Шекспир? О! Это был великий знаток человеческого сердца [...] Пушкин? Какая красота! Какая легкость и безыскусственность... [...] Вагнер? Вот где музыка будущего!"17 i pewnej powierzchownej orientacji w aktualnych trendach, panujących wśród europejskich elit. „Студент-драгун знаком отчасти с современной французской беллетристикой и цитирует наизусть целые порнографические страницы из Золя, Мопассана, Катюль Мендеса, Лоти и Бурже. При этом он питает слабость к бульварным французским восклицаниям [...]"18.

Kijowskie panny z dobrych domów (Будущая Патти) także prezentują pewien poziom "światowości" chcąc koniecznie zostać wybitnymi śpiewaczkami. W tym celu ich rodzice opłacają lekcje u włoskich "mistrzów", których pojawienie się w mieście obwieszcza lokalna prasa: „[...] вот и в газете напечатано, что какойто вновь прибывший профессор Маккарони «ставит» самые дурные и испорченные голоса... К тому же и дешево" 19 . W tym i wielu innych fragmentach pojawia się charakterystyczne dla kuprinowskiego obrazu Kijowa zespolenie wielkomiejskich ambicji z prowincjonalną mieszczańską trywialnością. Dumny student w galowym mundurze z Chreszczatyka okazuje się zadłużonym hulaką, który nie przyznaje się do własnej matki, oddającej ostatnie grosze na wykształcenie syna; przyszła "gwiazda" rosyjskiej opery pobiera lekcje nie u włoskiego maestro, a u zbiegłego włoskiego katorżnika; z właścicielki kwater studenckich przy bliższym poznaniu wychodzi wulgarna i prostacka natura. Ta ostatnia barwna postać pojawia się w szkicu Właścicielka mieszkania (Квартирная хозяйка). Pod maską uprzejmej damy z dobrymi manierami („В разговоре любит употреблять иностранные слова, а квартиранта непременно называет „мусью”"'20) kryje się kobieta zupełnie innego typu („Она толста, нечистоплотна, ходит целый день в широкой белой ночной кофте; лицо у нее красное, решительное, голос резкий, манеры и жесты воинственные" ${ }^{21}$ ), która jest w stanie wspólnie ze swoim konkubentem bez żadnych sentymentów wyrzucić zimą biednego studenta na bruk.

Przedstawiając kijowską rzeczywistość Kuprin niejednokrotnie powraca do typowości pewnych jej elementów nie tylko w skali miasta, ale też całego Imperium Rosyjskiego. Przykładem może być zgłębione przez Gorkiego zjawisko "bosiactwa", o którym mowa jest także w Kijowskich typach. „В Петербурге его называют «вяземским кадетом», в Москве - «золоторотцем», в Одессе - «шарлатаном», в Харькове - «раклом». В Киеве имя ему — «босяк»"22. Aleksander Kuprin $\mathrm{z}$ właściwą sobie tendencją do typologizacji, nieustannie zestawia miejskie realia z ogólnorosyjskim kontekstem, ukazując na pewną typowość kijowskiej rzeczywistości, która przez niego — Rosjanina przecież — nie była odbierana jako środowisko obce czy egzotyczne. Dawała ona materiał do rozważań o wspólnych dla całego

16 А. Куприн, Киевские типь: Студент-драгун, [в:] Его же, Собр. соч., в 9-ти томах, Москва 1970, том 1, с. 383.

17 Там же, с. 384

18 Там же.

19 А. Куприн, Киевские типь:: “Будущая Патти”, [в:] Е го же, Собр. соч., в 9-ти томах, Москва 1970, том 1, с. 389.

20 А. Куприн, Киевские типы: Квартирная хозяйка, [в:] Его же, Собр. соч., в 9-ти томах, Москва 1970, том 1, с. 399.

${ }_{21}$ Там же.

${ }_{22}$ А. Куприн, Киевские типь: Босяк, [в:] Его же, Собр. соч., в 9-ти томах, том 1, Москва 1970, c. 402. 
Imperium Rosyjskiego problemach i zjawiskach, z czego w pewnym sensie thumaczyli się już wydawcy "Kijowskiego słowa" w przedmowie do jednego ze szkiców Kuprina. „На этот раз, чтобы избежать упреков в том, что некоторые из наших очерков носили, так сказать, всероссийский характер, мы постараемся не выходить из сферы киевской жизни с ее особенностями и жаргоном"23.

Należy jednak jeszcze raz podkreślić, że poza przedstawieniem uniwersalnych zjawisk i problemów w obrazach Kijowa, pojawiających się w utworach Kuprina, pisarz zdołał uchwycić wyjątkowy koloryt lokalny miasta. Dotyczy to przede wszystkim zjawiska wielokulturowości, nierozerwalnie związanego z krajobrazem przedrewolucyjnego Kijowa. Już w warstwie językowej Kijowskich typów oraz późniejszych utworów Kuprina wyraźnie odzwierciedlony jest obraz różnorodności kulturowej miasta. Ten fakt wydaje się zrozumiały, jeśli uwzględnić jedno ze wspomnianych wcześniej “przykazań” pisarza: „Передавая чужую речь, схватывай в ней характерное: пропуски букв, построение фразы. Изучай, прислушивайся, как говорят. Живописуй образ речью самого говорящего. Это одна из важнейших красот... для уха" 24 . Autor Jamy w praktyce realizował przytoczone założenie, na co zwracali uwagę także inni znawcy kijowskich realiów, a mowa tutaj ponownie o Konstantinie Paustowskim: „Куприн с удивительным чувством меры и умением пользовался родственными русскому языками (в частности, украинским), [...] свободно владел способностью характеристики [...] при помощи языковых особенностей, при помощи диалога"25.

Rzeczywiście, w utworach Kuprina przy okazji przedstawiania specyfiki kijowskiej rzeczywistości, pojawiają się całe fragmenty tekstu, których język należałoby określić (z drobnymi uwagami) jako ukraiński. Przykładem może być w tym wypadku szkic Fatszywy świadek (Лжесвидетель, 1895), w którym świadek Mastodontow wypowiada następującą kwestię: „,...] Иду я по Хвундуклеевской улыци... тильки бачу, якись чоловик... несе якись сапоги. Я ему кажу...”26. Ukrainizmy pojawiają się także w wypowiedziach samego narratora, jak chociażby określenie "щурьий”27 (od ukr. "щур" - szczur) zamiast rosyjskiego "крысиный” (od ros. "крыса" szczur). Obraz środowiska językowego współczesnego Kuprinowi Kijowa wzbogacają także polonizmy, w sposób swobodny wplatane do tekstu. W Gwieździe Salomonа (Звезда Соломона,1917), która w dużym stopniu jest umiejscowiona w alter ego Kijowa $^{28}$, z ust jednego z bohaterów pada fraza „более змраду, як потехи”"29, której polskie pochodzenie jest wprost wskazane w tekście. W opowiadaniu Rzeka żyсіа (Река жизни, 1906) pojawiają się natomiast oczywiste dla polskiego czytelnika i mogące się wydawać egzotycznymi słowa typu "гицель" (pol. "hycel”) czy “лайдак" (pol. "łajdak"), wypowiadane przez właścicielkę hotelu "Serbia" Annę Fridrichownę, pół-Niemkę, pół-Polkę, gotującą swoim dzieciom "бигос по-польски" Trudno o bardziej barwną postać, która by na tyle dobitnie ukazywała całą złożoność i wielobarwność Kijowa przełomu XIX i XX wieku.

${ }^{23}$ Цит. по: А. Волко в, Творчество А. И. Куприна, Москва 1981, с. 19.

${ }^{24}$ Цит. по: А. Афанасье в, указ. источ., с. 157-158.

${ }^{25}$ К. Паустовский, указ. источ., с. 21.

26 А. Куприн, Киевские типь: Лжесвидетель, [в:] Его же, Собр. соч., в 9-ти томах, Москва 1970, том 1.

${ }^{27}$ А. Купр и н, Киевские типы: “Ханжушка”, [в:] Е го же, Собр. соч., в 9-ти томах, Москва 1970, том 1 .

${ }^{28}$ Kwestię związku Gwiazdy Salomona z kijowskimi realiami i Mistrzem i Małgorzata Mic haiła Bułhakowa dokładnie omawia Miron Piotrowski, patrz: М. Петровский, указ. источ., с. 198-217.

${ }^{29}$ А. Купри н, Звезда Соломона, [в:] Е го же, Собр. соч., в 9-ти томах, Москва 1973, том 7.

${ }^{30}$ А. Куприн, Река жизни, указ. источ., с. 269. 
Uchwycenie "smaczków" kijowskich realiów nie byłoby możliwe, gdyby nie wspomniane podejście Kuprina, na które zwrócił uwagę $\mathrm{m}$. in. A. Wołkow: „Особенно поражает в купринских фрагментах внимание к деталям, исключительная правдивость в воспроизведении фактов, иногда почти протокольная точность описаний”з1.

Obecny w Kijowskich typach koloryt lokalny nie zmiana jednak faktu, że miasto już na zawsze pozostało dla Kuprina przestrzenią, scenerią dla ukazania uniwersalnych problemów ${ }^{32}$. W charakterze przykładów można przywołać w tym wypadku wspomniane wcześniej opowiadanie Rzeka życia, które w dużej mierze jest rozwinięciem szkicu Właścicielka mieszkania ${ }^{33}$, oraz powieść Jama - oba utwory napisane już poza Kijowem.

W pierwszym z nich Kuprin zastosował charakterystyczny dla siebie chwyt i nie nazwał miasta, w którym rozgrywa się akcja opowiadania. Jednak wiele szczegółów, w tym obecność Dniepru, wskazuje wyraźnie na kijowskie realia. Z łatwością rozpoznał je m. in. Konstantin Paustowski: „Мне пришлось еще юношей жить в таких же киевских номерах, как купринская «Сербия», и каждый раз, когда я перечитываю этот рассказ, он меня поражает своей типичностью" ${ }^{34}$. W Rzece życia kuprinowski bohater-samobójca właśnie w Kijowie formułuje proroctwo odnośnie zbliżającego się nieuniknionego załamania społeczno-politycznego porządku, panującego w carskiej Rosji ${ }^{35}$. „Река жизни - как это громадно! Все она смоет рано или поздно, снесет все твердыни, оковавшие свободу духа. [...] Может быть, не далее, как через год она хлынет на весь этот огромный город, и потопит его, и унесет с собою не только его развалины, но и самое его имя!" $36 \mathrm{~W}$ przytoczonym fragmencie Kijów staje się symbolem całej Rosji, wręcz jej uosobieniem. Mieszkając w Petersburgu, Kuprin nieprzypadkowo wybiera jako miejsce akcji kijowskie realia - miasto pozostaje bowiem w świadomości pisarza miejscem, w którym skupiły się najbardziej typowe cechy Imperium Rosyjskiego, a które w przyszłości miały się przyczynić do jego upadku.

Powieść Jama, która także porusza problem nie ograniczający się do kijowskiej rzeczywistości, a mianowicie ukazuje kryzys moralny społeczeństwa rosyjskiego na przykładzie życia domu publicznego, również została osadzona przez Kuprina w kijowskich realiach. Wprawdzie, choć, jak twierdził sam autor, ,Яма - это и Одесса, и Петербург, и Киев" ${ }^{37}$, to jednak takie obrazy, jak przejażdżka łodzią po Dnieprze przy akompaniamencie ,звучных малороссийских песен" ${ }^{\prime 38}$, ewidentnie wykluczają pierwsze dwa miasta. Ponadto w tekście można znaleźć zakamuflowane wątki autobiograficzne, jak na przykład „Dnieprowskie słowo” — czasopismo, dla którego pracuje wyrażający główne myśli bohater Jamy, dziennikarz Płatonow. Sam Kuprin, natomiast, którego biografia w dużej mierze zbiega się z historią bohatera, pisał dla "Kijowskiego słowa", tak jak Płatonow pracował też w porcie. W utworze z łatwością da się także zauważyć obecność charakterystycznych dla kijowskiej przestrzeni obiektów, chociażby Ławry, ,наиболее чтимой и наиболее богатой среди

31 А. В ол ков, Творчество А. И. Куприна, Москва 1981, с. 20-21.

32 Na takie znaczenie Kijowa w twórczości Kuprina zwrócił już uwagę Miron Piotrowski, patrz: М. Петровский, указ. источ., с. 197.

33 А. Афанасьев, указ. источ., с. 19.

${ }^{34}$ К. Паустовский, указ. источ., с. 18.

35 Motyw przeczucia nadciągającej rewolucji przyczynił się niewątpliwie do wzmożonego zainteresowania Rzeka życia ze strony radzieckich literaturoznawców.

${ }^{36}$ А. Куп рин, Река жизни, указ. источ., с. 284.

${ }^{37}$ Цит. за: А. В олко в, указ. источ., с. 296.

38 А. Куприн, Яма, указ. источ. 
известных монастырей России" 39 . Kuprin nieprzypadkowo odwołuje się do roli Kijowa jako duchowego centrum Rusi, gdyż pozwala to pisarzowi dobitniej zdemaskować upadek moralny współczesnego mu społeczeństwa rosyjskiego.

Kijów w twórczości Kuprina pełni zatem rolę szczególną, stając się symbolem rosyjskiej duchowości, tradycyjnych wartości, ale także wypaczeń, które przeżerały Imperium Rosyjskie od środka - niepodważalną wydaje się zatem nierozerwalność w odczuciu pisarza miasta nad Dnieprem z pojęciem ojczyzny. Aleksander Kuprin dopełnia zatem plejadę rosyjskich pisarzy, w świadomości których Kijów przy całej swojej specyfice był postrzegany jako integralna część ogólnorosyjskiej przestrzeni, także w wymiarze duchowym i kulturowym. Autor Jamy utrwalił zatem obraz wielokulturowego Kijowa, którego historia nie może być postrzegana jako spuścizna wyłącznie jednego narodu.

39 Там же. 